\title{
The Rise and Fall of Justice Holmes
}

\section{G. Edward White†}

Occasionally the American nation sees itself in the life of one of its citizens. Something about the experiences, background, attitudes, or accomplishments of an individual seems particularly evocative of American culture, or at least a vision thereof. Such a life was that of Justice Oliver Wendell Holmes. In addition to being a man of great popular appeal, ${ }^{1}$ Holmes has held considerable interest for the intellectual community. From the publication of Holmes's The Common Law in 1881 until the present day, legal scholars, philosophers, political scientists, historians, literary critics, and journalists ${ }^{2}$ have attempted to understand and articulate the qualities that have made Holmes, in their eyes, an especially noteworthy representative of American civilization. This article traces the changing image of one man in the eyes of American intellectuals through the years-the "rise and fall" of Justice Holmes.

\section{INTRODUCTION}

American intellectuals have focused on Holmes in three capacities: as Brahmin, as ideologue, and as stylist. The shifting image of Holmes in the American scholarly community reflects changes in the attitude of intellectuals toward Holmes in each capacity.

The term Brahmin suggests Holmes's close association with a Boston tradition of social privilege and intellectual enterprise. During the twenty years following Holmes's birth in 1841, Boston and its surrounding countryside produced the first major concentration of intellectual activity in American history. The individuals who made contributions,

$\uparrow$ Member of the District of Columbia Bar. The author wrote this article as Visiting Scholar, American Bar Foundation, 1970-71. He is indebted to Folly Hartstone Rose of the New York University Law School for assistance in its preparation.

1 Holmes has been the only Supreme Court Justice in American history whose life has been the subject of a Broadway play, The Magnificent Yankee, which appeared in 1951.

2 The enumerated groups compose the "American intellectual community" for the purposes of this essay. Journalists include writers for the New York Times, the New York Herald Tribune, the Christian Science Monitor, and certain periodicals of popular scholarship, such as the Nation and the New Republic. 
which ranged from discoveries in natural science to poetry, were from wealthy or socially respectable families. Many had traveled to Europe in their youth, some for educational purposes; many had attended Harvard College, some also reading law for a time; a distinct minority, such as the Adamses, had served in the government. ${ }^{3}$

Of those names associated with Brahminism-Parkman, Agassiz, James, Lowell, Emerson, Longfellow, Parker, to list some-that of Holmes was among the most celebrated. At his son's birth Dr. Oliver Wendell Holmes, Sr. had already gained notice for an emotional appeal on behalf of the threatened U.S. Constitution. ${ }^{4}$ During Holmes's youth his father had enhanced his professional status with an influential paper on puerperal fever ${ }^{5}$ and ultimately emerged as the leading social historian of his time with the publication of The Autocrat of the Breakfast Table. ${ }^{6}$ The success of the elder Holmes and the equal success of Holmes, Jr. in a different area of endeavor, coupled with an unmistakable tension between father and son, ${ }^{7}$ has served as a starting point for scholarly explorations into the relationship between Holmes and his heritage. The explorations have revealed a relationship rich in ambiguities.

The Brahmins were "gentlemen" at a time when that style of life was still considered a profession. Gentlemanliness stood not only for educated refinement in intellect, taste, and culture, but also for snobbishness and class consciousness. There is abundant evidence that Holmes was as fastidious, clubbish, and condescending as any of his peers. ${ }^{8}$ Moreover, he possessed high intellectual standards and was generally critical of even those works he considered worth reading. ${ }^{9} \mathrm{He}$ also held rather elitist political views, confessing late in his life that the only justification he found for a government's undertaking to rectify social ills was "an aristocratic assumption that you know what is good for them better than they (which no doubt you do)."10

3 See generally V. Broors, THe Flowering of NEW ENGLANd (1936).

4 O.W. Holmes, Sr., Old Ironsides, Boston Daily Advertiser, Sept. 16, 1830.

5 O.W. Holmes, Sr., The Contagiousness of Puerperal Fever, NEW ENGLAND J. Medicine AND SURGERY, Apr., 1849.

- O.W. Holmes, SR., The Autocrat of the Breakfast Table (1858); see M. Howe, HolMES OF THE BREAKFAST TABLE (1939).

7 See C. Bowen, Yankee from Olympus (1943); M. Howe, Justice Oliver Wendell Holmes: The Shaping Years, 1841-1870 (1957).

8 See Hamilton, On Dating Justice Holmes, 9 U. CHr. L. REv. 1 (1941); Kurland, Portrait of the Jurist as a Young Mind, 25 U. CHI. L. REv. 206 (1957); Llewellyn, Holmes, 35 Colum. L. REv. 485 (1935); Sergeant, Oliver Wendell Holmes, 49 NEW REPublic 59 (1926).

8 Hamilton, supra note 8; Llewellyn, supra note 8.

10 Letter from Oliver Wendell Holmes to Harold Laski, July 23, 1925, in 1 HolmrsLASKI L.ETTERS 762 (M. Howe ed. 1953). 
Alongside these aristocratic characteristics, however, existed countertendencies. After a convivial youth as Harvard undergraduate and clubman, Holmes largely withdrew from social contacts with his peers for approximately ten years. He had virtually no intimate friends during his adult life, but his major correspondence friendships were with nonBrahmins. Although he fervently desired to make an intellectual name for himself before his fortieth birthday, ${ }^{11}$ he was contemptuous of his father's role as all-purpose man of letters. ${ }^{12}$ If Holmes favored government by elites, he believed in sharply curtailing the powers of the elitist judicial branch;13 if he "loathe[d] the thick-fingered clowns we call the people ... - -vulgar, selfish, and base,"14 he praised "that instinct that makes the American unable to meet his fellow man otherwise than simply as a man."15

Holmes's ideology was as ambiguous as his identification with his heritage. He emerged from adolescence an agnostic and an opponent both of time-honored moral pieties and of inexorable axioms governing scholarship. Later in his life, his agnosticism merged with a theory of government that stressed the importance of power relationships. Nevertheless, he retained an apparently passionate devotion to the act of believing in ideals-as distinguished from any particular ideals themselves - and a faith in the redeeming powers of social evolution. The combination of these potentially contradictory precepts has confounded those who have studied Holmes as ideologue. The "nutshell" words for Holmes abound: positivist, ${ }^{16}$ Darwinist, ${ }^{17}$ skeptic, ${ }^{18}$ cynic, ${ }^{19}$ idealist, ${ }^{20}$ romanticist, ${ }^{21}$ mystic, ${ }^{22}$ progressive, ${ }^{23}$ patriot. ${ }^{24}$ Each suggests an aspect of his thought, but no one word can accurately describe the whole.

Holmes has been equally interesting to American intellectuals as a

11 M. Howe, Justice Oliver Wendell Holmes: The Proving Years, 1870-1882 (1963).

12 M. Howe, supra note 7, at 19-21.

13 E.g., Lochner v. New York, 198 U.S. 45, 74 (1905) (dissenting opinion).

14 Quoted in Touched with Fire: Civil War LetTERS ANd Diary of OlIVER Wendell HoLMES, JR. 71 (M. HOWE ed. 1947).

15 Quoted in The Occasional Speeches of Justice Oliver Wendeill Holmes 25 (M. Howe ed. 1962).

16 Howe, The Positivism of Mr. Justice Holmes, 64 HARv. L. REv. 529 (1951).

17 Rogat, Mr. Justice Holmes: A Dissenting Opinion, 15 StAN. L. REv. 3, 254 (1963).

18 M. LeRner, The Mind and FatTh of Justice holmes (1943).

19 Mencken, The Great Holmes Mystery, 26 AMERuaA Mercury 123 (1932).

$20 \mathrm{M}$. Howe, supra note 7.

21 Id.

22 Boorstin, The Elusiveness of Mr. Justice Holmes, 14 NEW ENGLAND Q. 478 (1941).

23 R. FaulkNer, The JURISPRUdeNCE of John Marshal. 227-28 (1968).

24 Villard, Issues and Men: The Great Judge, 140 NATION 323 (1935). 
judicial stylist. In a profession in which the mode of expression characteristically has been technical, formal, depersonalized, and restrained, Holmes's opinions are remarkable for their absence of technicalities, their informality, their liveliness, and their poetic flights of language. Holmes's style is better described as a deviation from the judicial norm than as an improvement on it. If clarity, precision, and "reasoned elaboration" 25 can be said to be ideals of judicial opinion writing, Holmes appears to have eschewed these goals in the pursuit of terseness and ambiguity. His opinions have been called as difficult to understand as they are easy to read. ${ }^{26}$

In each of the above capacities, then, Holmes is not only interesting but controversial. As Brahmin, he provokes comment at two levels: his position evokes the tension of social privilege and intellectual superiority in an increasingly socially mobile and mass-educated society; his behavior contains the emotional conflict inherent in a man rejecting his social heritage. As ideologue, his stances raise a series of questions, among them whether power should be the controlling basis of social arrangements and whether social evolution is inevitable. As stylist, his method of judicial communication invites inquiries as to the value of a decision-making process that expresses its conclusions by unelaborated formulae.

The ambiguities and controversy surrounding Holmes have emerged as his image has changed in the eyes of the American intellectual community. Commentators have woven his thoughts and attitudes into their own social, political, or intellectual preoccupations. As those preoccupations have shifted, the image of Holmes has changed accordingly.

\section{The Changing Image of Justice Holmes}

Holmes's image may be evaluated in six time segments: (1) 1881 (publication of The Common Law) to 1902 (appointment to the Supreme Court), (2) 1903 to 1931 (retirement from the bench), (3) 1932 to 1940, (4) 1941 to 1949 , (5) 1950 to 1959 , and (6) 1960 to the present. Broadly speaking, each time segment is marked by a dominant intellectual attitude; these attitudes I have termed scientism, progressivism, hero worship, demythology, a sense of alienation, and libertarianism-egalitarianism. The time segments are, of course, only approximations for the sake of convenience, since changes in intellectual attitudes do not occur with chronological precision. The segments are intended to convey a general sense of the points in time at which one overriding per-

25 Cf. H. Hart \& A. Sacks, The Legal Process (tentative ed. 1958).

26 Rogat, supra note 17, at-9-10." 
ception of Holmes began to be replaced by another, rather than to demarcate any abrupt changes in intellectual attitude.

The term "image," as used in this article, is a construct representing the perceptions of a variety of articulate individuals about a public figure. Like any construct employed to derive collective meaning from individual attitudes, it is imperfect. This imperfection flows from the diversity of intellectual viewpoints during any historical period. The primary purposes of this investigation of Holmes's reputation are to emphasize the complexity of the process by which the reputation of a judge is established and to demonstrate the way in which the image of a man is shaped by the attitudes of his critics.

\section{A. 1881-1902: Holmes as Scientist}

The late nineteenth century intelligensia in America were obsessed with what would now be known as model building. Religious and spiritual principles appeared to them to have been made obsolete by more measurable rules of science. The universe, they had discovered, could be explained in terms of recurrent, predictable phenomena such as evolution and competition. Holmes's The Common Law, his contemporaries felt, was in the mainstream of the scientific movement in that it systematized jurisprudence on the basis of observable social phenomena rather than through intellectual abstractions. The theories advanced by Holmes; such as the external standard of liability in tort law, were said to rest on "a series of scientific observations" and were thought to indicate "the advance which the common law is now making toward a more scientific structure than it has ever before possessed." 27 By announcing that the felt necessities of the time governed the formulation of policy in the courts, Holmes was setting forth a tangible set of materials on which to erect a jurisprudential system, hence bringing "the ... office of the courts ... into unaccustomed clearness." 28 By 1899 a commentator announced that The Common Law was "everywhere regarded as a scientific work."'29

Scientism, in the late nineteenth century, was intellectual radicalism, since it attempted to shift the source of scholarly axioms away from the intuitions and abstractions of an educated elite of religious believers. To believe in science was to challenge established faiths. Insofar as it questioned a set of traditional social values, scientism was associated with political radicalism, and there were those who thought that

27 Book Review, 26 AlbaNy L.J. 484, 486 (1882).

28 Book Review, 15 AM. L. Rev. 381 (1881).

29 Note, 33 AM. L. Rev. 753, 754 (1899). 
Holmes had tendencies in this direction. In 1899 two law reviews labeled Holmes a radical, pointing particularly to his dissent in Vegelahn $v$. Guntner, ${ }^{30}$ in which Holmes had disassociated himself from a majority ruling upholding an injunction prohibiting peaceful picketing by strikers and had announced that "combination [on the part of labor] is a necessary and desirable counterpart [of combination on the part of capital] if the battle is to be carried on in a fair and equal way." 31 Reviewers found such "radical" language "strange . . . from a man of [Holmes's] environments." 32

Late nineteenth century intellectuals were most interested in Holmes as ideologue. His privileged social position was not regarded as significant to commentators-the only negative remarks made about Holmes's heritage were issued by Wendell Phillips, himself a Brahmin, who complained in 1895 about the unfortunate tendency of Holmes and other of his contemporaries to equate war with heroism. ${ }^{33}$ As a stylist, Holmes suffered from too facile an identification with his father. Those who attempted to analyze his opinions or writings invariably prefaced their remarks with a reference to the literary contributions of Dr. Holmes. At his sixtieth birthday, after twenty years on the Massachusetts bench, Holmes had not fully emerged as a unique and original figure. What reputation he had made for himself by 1902 flowed mainly from his efforts to make the study of the law more scientific.

\section{B. 1903-1931: Holmes as Progressive}

The late nineteenth century intellectual community insisted that formal logical arguments rest on a more scientific foundation than intuitive personal insights, but it was by no means prepared to abandon the use of abstract, deductive reasoning as an academic and pedagogic tool. Syllogistic reasoning from assumed intellectual principles represented the primary mode of thought and expression of the time. After 1900, however, not only the content of particular academic axioms but the formalistic reasoning process itself came increasingly under attack. ${ }^{34}$ Antiformalism in the early twentieth century intellectual community was a manifestation of the broader ideological movement known as progressivism. Progressivism emphasized the constantly changing nature of society and the need for testing social propositions and intellectual theories on the basis of contemporary experience. It

30167 Mass. 92, 104 (1896).

31 Id. at 108.

32 Note, Judge Holmes' Opinions, 60 ALbany L.J. 118 (1899).

33 Phillips, Sentimental Jingoism, 61 Nation 440 (1895).

34 Cf. M. White, Social Thought in AMerica (1968). 
resisted abstractions that could not be shown to be responsive to modern social conditions and was consequently hostile to intellectual discourse that appeared to rest on untested or untestable assumptions. In particular, progressivism denied the existence of permanent "laws" that governed intellectual disciplines. It preferred dominant academic or ideological trends to emerge through a process of experimentation whereby those ideas or policies that proved useful in achieving "progress" achieved dominant status until they were replaced by still more "progressive" concepts. ${ }^{35}$

In its political form, the progressive movement believed in the management of government by experts responsible to but not deferential toward the public. Progressives sought to expand the public sector of government in order to substitute decision making by an educated, efficient group of impartial administrators for decision making by partisan representatives of special interest groups. Progressive public policy envisaged the expansion of the executive branch of government, primarily in the form of administrative regulatory agencies, at the expense of Congress and the courts. Progressives urged federal or state legislation that attempted to create executive regulatory schemes and demanded a large measure of judicial tolerance for such legislation. They were particularly incensed at the attempts by judges to substitute nineteenth century economic axioms for empirical analyses of contemporary economic conditions. ${ }^{36}$

The reexamination of American social values stimulated by progressivism led ultimately to a reexamination of the movement itself. In its early years, at the opening of the twentieth century, the movement simultaneously embraced empirical relativism and moral absolutism, advocating social change in accordance with time-honored standards of behavior, such as honesty, industry, and temperance. But as its adherents became more impressed with the impermanence of ideas and institutions, they came to question the inviolability of their once-cherished moral principles. The result was a sweeping attack on the dominant social mores of the late nineteenth century, which were dismissed as "Victorian" and "Puritan."

Holmes's career on the Supreme Court coincided with the dominance of progressivism as an intellectual force in American life. His relationship with the movement itself was complex. Insofar as progressivism meant social or political reform, Holmes had little sympathy for

35 Cf. D. Noble, The Paradox of Progressive Thought (1958).

36 Cf. White, The Social Values of the Progressives: Some New Perspectives, 70 S. ATLANTIC Q. 62 (1971). 
the movement. In 1915 he told John Wigmore that "the squashy sentimentalism of a big minority of our people about human life" made him "puke." Among that minority Holmes placed those "who believe in the upward and onward-who talk of uplift, who think that something particular has happened and that the universe is no longer predatory." 37 Holmes continued to believe in nineteenth century concepts of classical economics, which the progressives repudiated, and nineteenth century social theories, such as that proposed by Malthus, which assumed an inherent imperfectibility in the bulk of mankind. He failed to share in any degree the progressives' faith in man's innate goodness or their missionary zeal to inculcate others with their moral beliefs. He remained throughout his life supremely indifferent to social welfare schemes of any sort, with the possible exception of eugencies. $^{38}$

Nevertheless, the progressives found Holmes an especially attractive and sympathetic judicial figure and contributed to the growth of his stature. By an accident of history, Holmes ascended the Supreme Court bench at a time when a series of constitutional issues were before the Court that progressives considered to be of great importance. The issues involved the constitutionality of state and federal legislative schemes, such as workmen's compensation and wages-and-hours regulation, in which governmental bodies asserted control over private economic relationships. This power the progressives regarded as essential to their campaign to reduce the influence of "special interests." In a series of opinions from 1903 to 1923, Holmes announced his willingness to tolerate legislative experiments and his contempt for judges who used constitutional provisions to further their own social or economic prejudices. ${ }^{39}$ The paradigmatic situation Holmes addressed in these years was that posed by Lochner v. New York, ${ }^{40}$ in which Justice Peckham, for the majority, had found a New York statute establishing maximum work hours for bakers inconsistent with the due process clause of the fourteenth amendment because it interfered with the right of laborers to work as many hours as they wished. Holmes found Peckham's position to be an artificial application of the so-called

37 Quoted in M. Howe, supra note 7, at 25.

38 Cf. Rogat, supra note 17, at 282-89.

39 E.g., Adkins v. Children's Hospital, 261 - U.S. 525, 567 (1923) (dissenting opinion); Truax v. Corrigan, 257 U.S. 312, 342 (1921) (dissenting opinion); Hammer v. Dagenhart, 247 U.S. 251, 277 (1918) (dissenting opinion); Adair v. United States, 208 U.S. 161, 190 (1908) (dissenting opinion); Lochner v. New York, 198 U.S. 45, 74 (1905) (dissenting opinion); Otis v. Parker, 187 U.S. 606 (1903).

40198 U.S. 45 (1905). 
liberty-of-contract doctrine ${ }^{41}$ in the face of conditions in the baking industry that rendered that doctrine meaningless. He stressed the reasonableness of beliefs on the part of New York legislators that the working environment of bakers was deleterious to their health and deferred to these beliefs, without endorsing the soundness of the maximum hours law itself.

Progressives considered Holmes's exposure of the deficiencies of abstract judicial reasoning and his tolerance for the programs of legislative majorities to be manifestations of judicial statesmanship of the highest order. In a series of articles, Felix Frankfurter celebrated Holmes for his ability to separate his personal views from his legal opinions, for his resistance to doctrinaire interpretation, for his understanding of social and economic forces, and for his willingness to allow legislative experimentation. ${ }^{42}$ Frankfurter's opinions were echoed by others, including James Tufts, ${ }^{43}$ Roscoe Pound, ${ }^{44}$ and John Dewey. ${ }^{45}$ Praising Holmes's grasp of "economic forces," Charles Carpenter declared in 1929 that "no judge who has sat upon the bench has ever been more progressive in his attitude." 46 Walter Wheeler Cook and Jerome Frank saw in Holmes's interpretation of his office the advent of a new school of jurisprudence. Cook asked rhetorically in 1921: "How many ... among law teachers, not to mention judges and practicing lawyers, ... 'consider the ends which [legal] rules seek to accomplish, the reasons why those ends are desired, what is given up to gain them, and whether they are worth the price?" "[M] ary work remains to be done," Cook maintained, "before the methods of legal thinking exemplified [by Holmes] become characteristic of . . . the leaders of the legal profession." 47 Frank, nine years later, hailed

41 Cf. Pound, Liberty of Contract, 18 YALE L.J. 454 (1909).

42 Frankfurter, The Constitutional Opinions of Mr. Justice Holmes, 29 HARv. L. Rev. 683, 691, 693, 694 (1916); Frankfurter, Twenty Years of Mr. Justice Holmes' Constitutional Opinions, 36 HARv. L. REv. 909, 927, 929 (1923); Frankfurter, Mr. Justice Holmes and the Constitution, 41 Harv. L. REv. 121, 132, 134 (1927).

43 "Holmes has . . . firmly set himself against a slack universe of legal conceptions and a rigidly fixed social order" and "has sought to give man room to express his advancing needs in an orderly progressing society." Tufts, The Legal and Social Philosophy of Mr. Justice Holmes, 7 A.B.A.J. 359 (1921).

44 Pound discussed Holmes's "conscious facing of the problem of harmonizing or compromising conflicting or overlapping interests .... Pound, 'Judge Holmes's' Contributions to the Science of Law, 34 HARV. L. REV. 449, 450 (1921).

45 Dewey stressed Holmes's "impatience with the attempt to settle matters of social policy by dialectic reasoning from fixed concepts" and his "faith that.. : our social system is one of experimentation, subject to the ordeal of experienced consequences." Dewey, Justice Holmes and the Liberal Mind, 53 NEW REPUBLIC 210, 211 (1928).

46 Carpenter, Oliver Wendell Holmes, Jurist, 8 ORE. L. Rev. 269, 270 (1929).

47 Cook, Book Review, 30 Yale L.J. 775, 776 (1921). 
Holmes for "abandon[ing], once and for all, the phantasy of a perfect, consistent, legal uniformity ...." "As a consequence," Frank felt, "whatever clear [sense] of legal realities we have attained in this country in the past twenty-five years is in large measure due to him. . . . [Holmes] has developed that remarkable tolerance which is the mark of high maturity. . . His legal skepticism is clear, sane, vital, progressive ...."48

One of the social issues to which progressives turned their attention was the place of social privilege in American society. On one level, progressivism was a movement to expand the classes of beneficiaries of governmental reforms and consequently to achieve a more egalitarian society. On another, it represented a reentry of social and intellectual elites into positions of public influence. In specific reforms such as the conservation movement, progressive rhetoric emphasized the importance of diffusing the power of monopolists and of improving the life style of small farmers, while progressive programs envisaged the management of conservation programs by an educated elite of technocrats. ${ }^{40}$ In general terms, social privilege was not itself regarded as an evil by progressives, provided that individuals of high status demonstrated a sense of social responsibility and a concern for the less fortunate classes.

With some strain, early twentieth century commentators sought to demonstrate these qualities in Holmes. They attempted this through association of Holmes with two symbols: the socially conscious Puritan and the aristocrat as democrat. The first symbol was an artful redefinition of Puritanism. For early twentieth century American intellectuals, Puritanism symbolized a moral rigidity and parochialism that came increasingly to be considered old-fashioned. But it also suggested an adherence to the dictates of one's conscience. Certain supporters of Holmes tended to stress his social conscience, which they linked to his Puritan heritage. They insisted that Holmes was "a Puritan whom doubt had civilized" so that his "Puritan strength" appeared not as a religious dogma but as a "simple conviction" that the democratic ideals of American civilization should be upheld.50 Life for Holmes was "a rich but a responsible adventure" in which the "natural Puritan aristocracy" functioned as caretakers of democracy. ${ }^{51}$

Thus Holmes, especially during his last years on the bench, came to be considered "an aristocrat with a genuine interest in the welfare

48 J. Frank, LAw ANd the Modern Mind 253, 257, 259 (1930).

49 Cf. G. White, The Eastern Establishment aNd the Western Experience (1968).

50 Littell, Books and Things, 3 New RepuBLIc 100 (1915).

ธ1 Sergeant, Oliver Wendell Holmes, 49 NEw Repubicic 59, 60 (1926). 
of the common man." 62 Those attracted to the symbol of Holmes as an aristocratic democrat emphasized the social implications of his free speech opinions. In these cases the defendants whose rights Holmes championed were conspicuously disadvantaged persons, being impoverished immigrants. ${ }^{53}$

Holmes's style was not controversial among members of the early twentieth century intellectual community. Their overriding concern was that judicial opinions not exhibit the abstract reasoning characterized by Roscoe Pound as "mechanical jurisprudence"; 54 on this point Holmes's opinions were eminently satisfying, since they eschewed that process altogether. Holmes's tendency toward formulaic expression was seen by commentators as fresh rather than cryptic. Judge Benjamin Cardozo, himself an aspiring stylist, remarked that "one almost writhes in despair at the futility ... of imitation or approach" upon confronting Holmes's "pointed phrases." 55

In his metamorphosis from scientist to progressive, Holmes stood on the threshold of deification. He stepped from his father's shadow by transcending his privileged background through tolerance and sympathy for thoughts and life styles foreign to his own. To observers of progressive persuasion his sense of the impermanency of ideas and intellectual axioms became "realism" or "sociological jurisprudence"; his willingness to defer to the wishes of those holding positions of political power became a belief in social experimentation; his tendency to believe that social upheavals were infrequent and that words alone rarely threatened the fabric of society became a faith in free speech; his general indifference to social problems and political issues became enlightened judicial self-restraint. He lacked only a historical vindication of his attitudes toward judicial decision making and political arrangements-which, after 1931, he received.

\section{G. 1932-1940: Holmes as Myth}

Reviewing in 1941 the ten years that had passed since Holmes's retirement, Walton Hamilton found that Holmes had emerged as a

52 Pollard, Justice Holmes, Champion of the Common Man, N.Y. Times, Dec. 1, 1929, $\$ 4$, at 4 , col. 1 .

53 E.g., United States v. Schwimmer, 279 U.S. 644, 653 (1929) (dissenting opinion); Schenck v. United States, 249 U.S. 47 (1919); Abrams v. United States, 250 U.S. 616, 624 (1919) (dissenting opinion). In the correspondence attendant upon the Schwimmer decision, in which WASP militarist Holmes made courteous replies to the tributes of Russian Jewish pacifist Rosika Schwimmer, readers saw another manifestation of the Brahmin's tolerance for ideologies and life styles alien to his own. See Sergeant, supra note 51, at 60 .

54 Pound, Mechanical Jurisprudence, 8 CoLuM. L. REv. 605 (1908).

65 Cardozo, Mr. Justice Holmes, 44 HARV. L. REV. 682, 689 (1981). 
"deity ... an Olympian who in judgment could do no wrong. His opinions were norms by which to measure the departures of his Court from the true path of the law." "The neat phrase, the quotable line," Hamilton observed, "were ultimates; and beauty of form was commuted into wisdom of utterance. For the Court, but especially in dissent, thus spake Holmes and the subject was closed." 56 The years from 1932 to 1940 witnessed the apotheosis of Holmes. His human qualities were enhanced in the eyes of the world: the moving radio address on his ninetieth birthday; ${ }^{57}$ the gracious retirement, accompanied by a memorable letter to his fellow justices; ${ }^{58}$ the tranquil declining years when, to one observer, his face fairly glowed with an inner radiance. ${ }^{59}$ His death, three days short of his ninety-fourth birthday, was cause for inspired reflection-here was a life that could be said to have been fully lived, in terms of both longevity and accomplishment.

Other elements contributed to the deification of Holmes. At a time when economic privilege was in disrepute but gracious life styles retained a romantic attraction, ${ }^{60}$ Holmes's role as transcendant Brahmin maintained its fascination. His brand of jurisprudence was labeled "realistic;" it served as an inspiration for legal scholars who desired to publicize the human and institutional factors operative in judicial decision making and to eradicate once and for all deductive logic from the judging process. ${ }^{61}$ His tolerance for experiments in legislation and his relativist approach to ideas contrasted sharply with the stubborn absolutism of the Justices who struck down New Deal legislative programs. As the primary responsibility for reform shifted from the states to the federal government, those who believed that a vast expansion of federal power and activity was needed to save the nation imagined that Holmes would have supported their efforts. He thus became a liberal as well as a realist.

The transcendant Brahmin theme was popularized by the appearance in 1932 of the first full-length biography of Holmes, written by the journalist Silas Bent. Holmes, for Bent, expanded the Puritan view of human nature-that man is inherently selfish-to a "noble conception of a realistic and rationalized science of law." He "perceived that jealousy and envy ... were in fact when sublimated the basis

56 Hamilton, supra note 8.

57 Reprinted in Justice Oliver WeNdell Holmes: His Book Notices and UNCOLlected LETTERS AND PAPERS 142 (H. Shriver ed. 1936).

58 Id. at 143.

59 C. BOWEN, YANKEE FROM OlyMPUS 413 (1943).

60 Cf. D. Wecter, The Great Depression (1948).

61 Cf. W. Rumble, american. Legal Realism (1965). 
of human justice." As a consequence, he came to advocate a mode of lawmaking that gave each man fair scope to pursue his own self-interest. Bent saw this as evidence that Holmes had "freed himself from the group loyalties and prejudices and passions which are a heritage of those reared in the security of the genteel tradition." "Never," he maintained, "was aristocrat less class-conscious."62 Others pursued this tack. "Of the many achievements of Justice Holmes," Adolf Berle wrote in 1935, "none is more glorious than that of transcending the bounds of his apparent emotional security." 63 Augustin Derby, a former clerk to Holmes, found him "the most democratic of men, ... entirely without pose." 64

If Bent polished Holmes's image as aristocratic democrat, Karl Llewellyn served a similar function in the emergence of Holmes as realist. Llewellyn had himself been one of the early and major spokesmen for realism-in 1930 and 1931 he had written law review articles that announced the emergence of a realistic jurisprudence which combined a sense of the sterility and artificiality of legal rules with a belief in the importance of manipulation and rationalization in governmental decision making. ${ }^{65}$ This point of view was not original, Llewellyn maintained; "Holmes' mind had travelled most of the road two generations back." 60

By the date of Holmes's death, realism had become a major intellectual force among American legal scholars. Llewellyn took the occasion to pay tribute to the contribution of Holmes to the movement. Because of Holmes's work, Llewellyn maintained, "it is no longer heresy to argue that judges have 'molecular' law-making power . . . . It is ... no longer heresy to argue that there is no brooding omnipresence in the skies, but that the true measure of law . . . is: what, in particular, can or will anybody do about it, here and now? It is no longer heresy to see constitutional law as a field in which economic forces, prejudices and personalities play in an intricate, semi-concealed game, law, politics and statesmanship together . . . ."67

62 S. BeNt, Justice OLIVER WENDELL Holmes (1932).

63 Berle, Justice Holmes: Liberal, 24 SURVEx Graphic 178 (1935).

64 Derby, Recollections of Mr. Justice Holmes, 12 N.Y.U.L.Q. REv. 345, 345-46 (1935). Max Lerner called Holmes "the very perfection and flowering of the New England aristocracy." Lemer, Book Review, 46 Yale L.J. 904, 908 (1937). Morris Cohen found him to have "intellectual power and the true liberal attitude that enabled him to rise above his hereditary class prejudices." Cohen, Justice Holmes, 82 NEw REPUBLIc 206, 207 (1985).

e5 E.g., Llewellyn, $A$ Realistic Jurisprudence-The Next Step, 30 CoLum. L. REv. 431 (1930); Llewellyn, Some Realism About Realism, 44 HARv. L. REv. 1222 (1931).

66 Llewellyn, supra note 65 , at 454 .

67 Llewellyn, Holmes, 35 CoLum. L. Rev. 485, 487-88 (1985). 
The most compelling image of Holmes in the nine years after 1931, however, was that of liberal. The major representation of him in that role was made by Felix Frankfurter in $M r$. Justice Holmes and the Supreme Court, published in 1938. Frankfurter had himself made the transition from progressive to New Dealer without strain ${ }^{68}$ - he saw the experiments of the Roosevelt administrations as enlightened recognition of the need to adjust social policies pragmatically in order to meet the demands of an increasingly complex civilization. In Frankfurter's view, Holmes "threw the weight of his authority on the side of social readjustments through legislation." Holmes analyzed "with . . . clarity the governing elements in the modern economic struggle," Frankfurter maintained, "[and] found nothing in the Constitution to prevent legislation which sought to remove some of the more obvious inequalities in the distribution of economic power." $\mathrm{He}$ "[did not] believe that there was anything in the Constitution to bar even a conscious use of the taxing power for readjusting the social equilibrium." $\mathrm{He}$ "was loath to find a governmental vacuum . . . where there was no intersection of federal and state authority." 69 In short, Holmes was an ancestral New Dealer, as he had been for Llewellyn an ancestral realist.

The intellectual community of the 1930s was quick to support Frankfurter's interpretation. Perhaps the most enthusiastic acclaim came from the New York Times, which described Holmes as the "liberal and lovable philosopher" whose "scores of opinions ... testif[ied] to his liberalism" liberal interpretations of the law in cases involving property rights and personal rights." 71 Upon Holmes's death the Times called him the "chief liberal of [the] supreme bench for 29 years." 72

The 1930s thus saw Holmes elevated to demigod by the intellectual community. ${ }^{73}$ If he had been "the idol of the progressives who

68 The transition was not so easy for others; many progressives parted company with the New Deal. See O. Graham, JR., AN ENCORE For REForm (1967).

69 F. Frankfurter, Mr. Justice Holmes ANd the Supreme Court 44, 36-37, 43, 86 (1938).

70 N.Y. Times, Jan. 13, 1932, § 1, at 3, col. 4.

$71 I d$. at col. 6.

72 N.Y. Times, Mar. 6, 1935, \& 1, at 1, cols. 2-3.

73 Amidst the shower of praise for Holmes in the 1930s came an occasionally querulous or critical note, foreshadowing a later shift in tone. H.L. Mencken felt that there was "no evidence in Holmes' decisions that he ever gave any really profound thought to the great battle of ideas that raged in his time." Holmes had "no ... genuine belief in democracy," Mencken argued, and his decisions demonstrated "a widespread and beautiful inconsistency." Further, the "peculiar salacity" of Holmes's opinions, which made them "interesting as literature," derived in Mencken's opinion from an "easy-going cynicism." Holmes, Mencken felt, "had a considerable talent for epigrams," and when "once his 
believed that America must evolve and change," 74 he was even more revered by the reformers of the 1930s, who had added to their criteria for statesmanship a commitment to majoritarian relativism and a "realistic" approach to social planning. Although he symbolized the grandeur of a more distant, and for some a more gentlemanly, era, he also appeared-particularly in light of the Court-packing crisis and the "switch in time"-distinctly a man of the times.

\section{194I-1949: Demythologizing}

Holmes's reputation had been too closely linked to an implicit set of social priorities not to be altered with the replacement of that set by another. His unequivocal deference to the whims of majorities was destined to become a subject of controversy as the intellectual community lost faith in the judgment of sheer numbers. As early as 1919 it had been suggested that Holmes believed "that there can be . . . no standard of evaluation except the principle that might makes right."75 In 1940 Lon Fuller had pursued a similar line of analysis in observing that Holmes's influence as a judge "fell far short of being commensurate with his general intellectual stature." Fuller attributed this condition to Holmes's "notion that the law is something severable from one's notions of what it ought to be."76 The absence of any overriding set of moral values in Holmes's jurisprudence caused increasing anxiety in the intellectual community after 1941, when ideals of civilization and justice seemed challenged in a variety of ways by the Axis powers.

The most sensational manifestation of this anxiety was a series of articles by Jesuit theologians and law professors which linked Holmes's ideology with that of totalitarian regimes. Between 1941 and 1943,

mood had brought him to this or that judgment the announcement of it was sometimes more than a little affected by purely literary impulse. ... [T] The result was . . . now and then ... far more literature than law." Mencken, The Great Holmes Mystery, 26 AMERIGAN MERCURY 128, 124 (1932). Kenneth Reiblich, in a 1939 analysis of Holmes's conflictof-laws opinions, found that "certain concepts seemed to be accepted [by Holmes] as apriori truths and applied with little indication of the realism which one might have expected to find." Reiblich found puzzling the "conviction that Mr. Justice Holmes, the liberal and realist, becomes in conflict of laws the conservative and conceptualist." Reiblich, The Conflict of Laws Philosophy of Mr. Justice Holmes, 28 GEo. L.J. 1, 12, 20-21 (1939). Meanwhile, Walter Nelles and Samuel Mermin had concluded that "in his approach to labor questions Holmes was free from all such sentimentality as is expressed in talk of 'human rights' or 'brotherhood of man.' There was no humanitarian softness in his head." Nelles \& Mermin, Holmes and Labor Law, 13 N.Y.U.L.Q. REv. 517 (1936).

74 Villard, Issues and Men: The Great Judge, 140 Nation 323 (1935).

75 Bode, Justice Holmes, Natural Law, and the Moral Ideal, 29 InTERNaT'L J. Ethics 397 (1919).

76 L. FUller, The LaW in QUest OF ITSELF 62-63 (1940). 
four critiques of this nature appeared. Two of the articles, written by Francis Lucey, attempted to show that Holmes's philosophy was "akin to Hitler's" and that if adopted "would be the death knell of our democracy."77 For Holmes, Lucey maintained, "there [were] no moral oughts, ... just plain, unadulterated physical force of the majority imposing itself on all." "If . . . Holmes was correct," Lucey concluded, "Hitler is correct."78 John Ford published a similar piece in 1942 which summarized Holmes's thought as follows: "The essence of law is physical force. Might makes legal right. The law is to be divorced from all morality. There is no such thing as a moral ought-it is a mere fiction. ... There is no absolute truth. ... There is too much fuss about the sanctity of human life. To the state man is a means to be sacrificed if necessary in the interest of the state. The ultimate arbiter of all life is physical force." These attitudes scandalized Ford, who saw them as the ultimate rationale for facist and communist dictatorships. ${ }^{79}$ The fourth such critique of Holmes, written by Paul Gregg, equated Holmes's "pragmatism"-a philosophy which for Gregg assumed that "ideas, logic, reason, morals, and all else, are merely tools by which plans of action are forged and made to work"-with "the latest social experiment in Nazi Germany." "Who can say," Gregg asked, "that the United States, at some future time, will not be dominated by bureaucrats whose social philosophy is kindred to that of Hitler, Goering, Goebbels, and Himmler?" "[T]otalitarianism and dictatorship," Gregg felt, "can live and flourish under pragmatism. . . . If totalitarianism ever becomes the form of American government, its leaders, no doubt, will canonize as one of the patron saints Mr. Justice Holmes. For his popularization of the pragmatic philosophy of law has done much to pave the way." 80

. The ideas advanced in these four articles were popularized by Ben Palmer in an essay entitled "Hobbes, Holmes, and Hitler," which appeared in the American Bar Association Journal in 1945. In Palmer's view, "the fact that Holmes was a polished gentleman who did not go about like a storm-trooper knocking people down and proclaiming the supremacy of the blonde beast should not blind us to his legal philosophy that might makes right, that law is the command of the dominant social group." Holmes's jurisprudence, for Palmer, sanctioned "the iron fist of absolute power wielded without possibility of

77 Lucey, Jurisprudence and the Future Social Order, 16 Sociac Scr. 211 (1941).

78 Lucey, Natural Law and American Legal Realism, 30 GEo. L.J. 493, 512, 531 (1942).

79 Ford, The Fundamentals of Holmes' Juristic Philosophy, 11 FordHaM L. Rev. 255, 275 (1942).

80 Gregg, The Pragmatism of Mr. Justice Holmes, 31 GEO. L.J. 262, 284, 293, 294 (1943). 
external restraint because of any protest of impotent individuals or minorities." "If totalitarianism comes to America," Palmer maintained, "... it will come through dominance in the judiciary of men who have accepted a philosophy of law that has ... its fruition in implications from the philosophy of Holmes."81

The association of Holmes with totalitarianism sparked a debate that was, in its ramifications, to preoccupy legal scholars in America for a further decade. At the core of the debate was the question whether the American legal system embodied any absolute moral principles or whether it merely exemplified contemporary social norms. In the 1940s it seemed especially distressing for American intellectuals, particularly those of a religious persuasion, to deny that lawmaking in the United States flowed from unalterable humanitarian principles. In other parts of the world, denial of such standards seemed to have created patently inhumane governments. America had made a commitment to combat these nations, and philosophies that assumed that "whatever works is right" appeared intolerable to those who supported this struggle.

The Jesuit attack on Holmes, then, was an extreme manifestation of a general tendency of intellectuals in the 1940s to reassess Holmes's philosophy in relation to their own thinking. At a time when "pragmatism" and "realism" had evolved, in some circles, from words suggesting progressive social reform to words heralding the coming of totalitarianism, one group of Holmes's critics maintained that such labels were inadequate to describe the breadth and depth of his character. These critics defended Holmes by emphasizing the complexities and contradictions in his thought. Daniel Boorstin suggested in a 1941 article that "the inadequacy of labels like 'liberal' and 'conservative' quickly appears" in describing Holmes. "In his earnestness to encompass all philosophies and yet to commit himself to none," Boorstin maintained, Holmes made "his personal world of ideas" one "of doubt and conflict." He "clearly felt the tug of opposing forces": his "New England conservative tradition" and his "intensely liberal individuality." 82 Max Lerner noted in Holmes "a deep conflict between skepticism and belief, between mind and faith, between a recognition that men act in terms of a cold calculation of interests, and a recognition also that they are moved by symbols." Holmes tried, in Lerner's view, "to construct a philosophy of life for himself which would allow him to take account of both strains." 83 Francis Biddle referred to Holmes's

81 Palmer, Hobbes, Holmes, and Hitler, 31 A.B.A.J. 569, $571-73$ (1945).

82 Boorstin, The Elusiveness of Mr. Justice Holmes, 14 NEw ENGLAND Q. 478, 480-81 (1941).

83 M. LERNER, The MIND AND FAITH of JUSTICE Holmes 373 (1943). 
"dualism of skeptic and moralist, of doubter and preacher." "He distrusted affirmations," Biddle felt, "yet ... made them with an oversimplification that was only partially concealed by the form of witty aphorism which they usually took." 84

To be sure, the 1940s were marked by some older images of Holmes. Felix Frankfurter persisted in emphasizing Holmes's ability to "transcend his emotional attachments." "New Englander of New Englanders in his feelings all his life," Frankfurter wrote of Holmes in 1944, "[he] disciplined himself against any kind of parochialism in his thinking.... He reached the democratic result by ... his disbelief in ultimate answers to social questions. Thereby he exhibited the judicial function at its purest."85 Morton White maintained that Holmes was "a serious comrade-in-arms of the liberal, progressive, and professional movement for reform" and felt that his "intellectual outlook was permeated with a good many of the ideas that were stirring the liberals of his time."s6 But the tone of the commentators had altered. If the Jesuit critics and their popularizers were regarded as aberrational, they nonetheless symbolized an unconscious decision by American intellectuals to, as Walton Hamilton put it, "elevate Mr. Justice Holmes from deity to mortality." 87 From that decision emerged a complex image of Holmes as a man whose thought and character contained contradictory forces and whose apparently facile self-assurance masked the considerable strain he must have felt in attempting to reconcile them. If the passions of the war-scarred 1940s stimulated some of the most savage evaluations of Holmes, they also generated some of the most mature.

\section{E. 1950-1959: Sense of Alienation}

Whatever Holmes had been to American intellectuals from 1880 through the 1940s, he had been relevant. His relationship to his heritage, his approach to constitutional issues, his jurisprudential principles had touched on powerful themes for the intellectual community. But after 1950, critics of Holmes tended increasingly to reveal their sense of the widening gulf between his world and theirs. The man who had been dateless for Hamilton in 1941 suddenly became dated.

The decade commenced with a continuation of the impassioned

84 F. Biddle, Mr. Justice Holmes 95 (1942).

85 Frankfurter, Oliver Wendell Holmes, 21 Dictronary of American BIography 417, 423 (1944).

80 M. WHITE, supra note 34 , at $104,74$.

87 Hamilton, supra note 8 , at 1 . 
debate that had begun in the 1940s. Harold McKinnon denounced Holmes's philosophy as "a symbol of our intellectual wretchedness, a conspicuous example of our abandonment of those spiritual, philosophical and moral truths that have been the life of the western tradition." 88 Father Lucey also returned to the attack, again comparing Holmes to Hitler. ${ }^{89}$ Supporters of Holmes continued to defend him. Fred Rodell wrote that "Holmes took pains to make clear . . . that his skepticism had never bred in him the cynicism of defeat and despair, and that, in the realm of ought-to-be, he held strong moral and ethical views concerning decency and justice among mankind."00 Mark DeWolfe Howe stated that Holmes "did not deny that a primary source of law is the realm of moral standards in which society has its being, and ... considered the first responsibility of the lawyer and judge to be that of bringing the law into conformity with those moral standards." Howe's essay was colored by a sense that his generation was affected by concerns that had not affected Holmes. The adverse criticism of Holmes's skepticism, Howe felt, was "partly the result of the glimpse which Hitler gave us of cynicism triumphant. We have begun to ask ourselves whether, despite Holmes, there are not some standards of decency so fundamental and so permanent that they may properly be described as absolute." Having experienced a sense of the depths of man's inhumanity to man, Howe and his contemporaries of the 1950s were not, in his judgment, "intellectually willing and emotionally able to accept that total skepticism which led Holmes to question whether man has a cosmic significance 'different in kind from that which belongs to a baboon or a grain of sand." "91 They needed to believe that moral principles buttressed the universe; that civilization imposed limits on man's behavior. "Holmes' words are read now," Henry Hart wrote in 1951, "when the foundations of all things are being re-examined. The moral claims of settled law in a constitutional democracy must not today be overlooked." 22 Holmes himself had not experienced the horrors of a wholly amoral world. Charles Wyzanski emphasized Holmes's faith in the ultimate triumph of reason. Wyzanski attributed this faith to the fact that "Holmes wrote before the world had fully appreciated the wickedness of which

88 McKinnon, The Secret of Mr. Justice Holmes, 36 A.B.A.J. 261, 345 (1950).

89 Lucey, Holmes-Liberal-Humanitarian-Believer in Democracy?, 39 GEO. L.J. 523, 548,553 (1951).

90 Rodell, Justice Holmes and His Hecklers, 60 YALE L.J. 620, 623 (1951).

01 Howe, The Positivism of Mr. Justice Holmes, 64 HARv. L. REv. 529, 544-45 (1951).

92 Hart, Holmes" Positivism-An Addendum, 64 HaRv. L. Rev. 929, 937 (1951). 
civilized man is capable. He knew not the Nazi concentration camps ... nor the Communist disciplined subordination of man's interest in truth to man's interest in material progress." 93

Intellectuals of the 1950s thus felt that Holmes's conclusions were founded on assumptions about the nature of man that differed from their own. This view led critics to treat him as a figure from another age, an approach that occasionally led to debunking ${ }^{94}$ or redefinition ${ }^{95}$ of his political views. In the main, however, alienation from Holmes took the form of attempts to place him at a distant point in time. This was the major thrust of the three principal books written about Holmes in the 1950s: Henry Steel Commager's The American Mind, Samuel Konefsky's The Legacy of Holmes and Brandeis, and Mark DeWolfe Howe's Mr. Justice Holmes: The Shaping Years. Commager identified Holmes with "the progressive movement['s] . . inability to fulfill itself without imposing far reaching readjustments upon the legal mechanics of economy." static" in "his conception of the economic universe" and maintained that his thought was "filled with a good many fallacies and superficial preconceptions which he assumed to be basic truths," including his "imperturbable confidence in the capacity of society to defy artificial

83 Wyzanski, The Democracy of Justice Oliver Wendell Holmes, 7 VAND. L. REv. 311,319 (1954).

94 Martin Hickman's "reappraisal" of Holmes revealed "a man arrogant beyond the ordinary, a man of narrow and oligarchical sympathies," whose "indulgence of the legislature ... rested at least as much on contempt as on tolerance." The stereotype of Holmes that he "was a champion of free speech and civil rights, that he was compassionate and solicitous for the defenseless," Hickman argued, was not supported by "an examination of the cases." There "is a hollow ring to the finely turned phrases." Hickman, Mr. Justice Holmes: A Reappraisal, 5 W. PoL. Q. 66, 83, 73 (1952). Merle Pusey, in his biography of Charles Evans Hughes, wrote that the "Holmes whom the judges knew had little in common with the humanitarian crusader of the same name who has so often been extolled in print. Holmes' brethren knew that he didn't care a straw for the 'social' or 'progressive' legislation that he was said to be heroically defending .... [They] were well aware of his scorn for any deviation from the result he thought the law required because that result might be 'unjust' to the individuals concerned." I M. Pusey, Crarles Evans HuGHES 287, 289 (1951).

95 Irving Bernstein announced that the "cherished American myth . . . that Oliver Wendell Holmes was a liberal" was "as baseless as the tale of Washington and the cherry tree." Holmes, according to Bernstein, was "as profound, as civilized, and articulate a conservative as the United States has produced." He was "a firm believer in capitalism who looked with distrust upon governmental intervention in economic life. Monopolies won his respect, while he regarded unions and strikes suspiciously .... Movements seeking the reform or reconstruction of economic society won his distrust. . . . Free speech for Holmes was a Darwinian arena in which ideas would struggle for survival. It was at the same time a prop of a conservative society." Bernstein, The Conservative Justice Holmes, 23 NEW ENGLAND Q. 435, 445, 449 (1950).

96 H.S. Commager, The AMErican Mind 374 (1950). 
meddling with its natural evolution." ${ }^{2}$ Howe saw Holmes's aesthetic judgment as "responsive to older modes of expression and earlier moods of feeling." His biography of Holmes, Howe observed, was largely "an essay in intellectual history."98

The works of the 1950 s presented a composite picture of Holmes as a man whose thought failed, despite its breadth, to encompass the problems of mid-twentieth century existence. A series of inevitabilities ruled Holmes's world: iron economic laws, natural selection of ideas and social policies, the continual progress of civilization. These inevitabilities marked the thought of an older age where, in light of a series of consoling faiths, men could afford to be skeptical. Life in the mature twentieth century, in the minds of American intellectuals, encouraged no such faiths.

\section{F. 1960-: Holmes and Libertarianism-Egalitarianism}

In the 1960s, attention turned to the problems caused by the inequalities and diversities among Americans. Integration-racial, psychological, cultural-became a dominant concept as the decade opened. Intellectuals emphasized once more the responsibilities of elites to those less privileged and stressed the fundamental values-liberty, democracy, egalitarianism, impartial justice-that bound Americans together. Critics of Holmes asked again whether he had understood the social obligations of leadership or the consensual values embedded in the process of lawmaking in America. Their answer, by and large, was negative on both counts. Critics alleged that as both a man and a judge Holmes had been indifferent to the needs of the underprivileged. They pointed to the distance Holmes felt between himself and less socially and intellectually privileged Americans, and to his apparent lack of concern for civil-liberties interests in certain cases.

"It would be easy ... to create the impression," Edmund Wilson wrote of Holmes in 1962, "that [he] was an egregious social snob of a peculiarly provincial kind." ${ }_{99}$ Commentators on Holmes as Brahmin did occasionally attempt to foster that impression, 100 but they were far more concerned with what Wilson called the "carapace of impenetrable indifference to current pressures and public opinion" in Holmes, "due partly to the impregnable security of belonging to the Boston 'Brahmin' caste."101 Distance, withdrawal, isolation, and detachment

97 S. KonefsKy, The LeGacy of Holmes and BRANDeis 59, 24, 64, 303 (1956).

$98 \mathrm{M}$. Howe, supra note 7, at 10 , vi.

99 E. WiLson, PATRIOTIC GORE 784 (1962).

100 E.g., Rogat, The Judge as Spectator, 31 U. CHI. L. REv. 213, 230 (1964).

101 E. WiLson, supra note 99, at 782-83. 
became the chief aspects of Holmes's Brahminism that interested critics. Mark DeWolfe Howe emphasized Holmes's prolonged withdrawal from society and his feeling that his destiny lay in areas, such as scholarship, that were isolated from the world at large. ${ }^{102}$ Yosal Rogat accentuated Holmes's "preoccupation with the theme of the observer-the spectator." "[His] participation in public, and perhaps even in private, experience had an attentuated quality," Rogat wrote, "and [he] withdrew, perhaps consciously, from important areas of shared human experience."103 Saul Touster provided a charitable explanation for Holmes's Brahmin detachment. "Holmes," Touster maintained, "was ... a profoundly injured spirit." "The deadening of sympathetic feelings, the Olympian aloofness, the spectator view, . . . the disbelief in causes" were devices "by which he somehow [could] gain distance from the world." Touster found that Holmes's "expressions of sympathy and doubt and feelings for the distress of the Negro were suppressed" in his later life; "suppression of feeling," he maintained, "may be the product not of the absence of feeling, but an excess of it."104

Others in the 1960s viewed aloofness in Holmes less sympathetically. Francis Biddle, in an otherwise laudatory assessment, described Holmes as "an aristocrat and a conservative" who "had little sympathy with the sufferings and failures of mankind, and no urgent desire to change their lot."105 Rogat felt that "to a remarkable degree, Holmes simply did not care. . . . Precisely because he thought that 'the crowd' was unwise, he expected them to destroy the way of life that he preferred. But he would have thought it immature to be deeply concerned about that imminent destruction." ${ }^{106}$ Robert Faulkner saw Holmes's skepticism and deference to majority views as manifestations of "a certain disdain toward minorities and the weak generally." 107

For intellectuals of the $1960 \mathrm{~s}$, belief in certain fundamental guarantees of equal treatment for minorities and certain permanent individual rights was an important aspect of enlightened social thought. In the context of their own full-blown libertarianism-egalitarianism, representatives of the American intellectual community found Holmes's response to civil liberties shocking. Rogat, the leading critic, set out to disprove the widely held belief that Holmes was a champion of civil liberties. In cases involving "various claims to civil and political rights

$102 \mathrm{M}$. Howe, suprá note 11 , at 1-8, 256 (1963).

103 Rogat, supra note 100, at 230.

104 Touster, In Search of Holmes From Within, 18 VAND. L. REv. 437, 470, 450-51 (1965).

105 F. Biddle, Justice Holmes, Natural Law and the Surreme Court 7 (1961).

106 Rogat, supra note 100 , at 255.

107 R. FAULKNER, THE JURISPRUdENCE OF JOHN MARShaLL 253 (1968). 
that arose out of the Civil War Amendments," for example, Rogat maintained that Holmes was "consistent" in "denying the claimed right" and "weighed the substantive claim to equality lightly." In alien cases Holmes "wrote as if anyone seeking entry was merely a suppliant." "Nowhere" did he "help in framing a remedy to secure a constitutional right. He did not develop further any inchoate right or liberty, or broaden the scope of those which were already established." In short, Rogat found that "the accepted image of Holmes as uniquely libertarian owes more to fantasies unloosed by the attractiveness of his personality than to the realities of his career." Holmes's striking insensitivity to civil rights and liberties stemmed, Rogat maintained, from a "fundamentally impoverished account of legal phenomena." $\mathrm{He}$ "did not sufficiently distinguish a crude system of social control, resting on naked power, from a distinctively legal method of control." $\mathrm{He}$ seemed "never ... to have perceived, and certainly never acknowledged, the extent to which general commitments to fairness, generality and neutrality are built into the idea of legality and constitute part of its meaning. ... Holmes spoke as if a legal sysem were simply a mechanism to enforce by whatever means, the desires of the dominant group," ignoring the extent to which law in America was premised on notions of equitable attention to the needs of minorities and guarantees of equal justice. ${ }^{108}$

Faulkner also found that an "orientation by moral and political ends [was] absent from Holmes' jurisprudence." Holmes, for Faulkner, "left vacant [the] essence [of judicial decision making]: a reasonable view of what constitutes justice in America." The "besetting and deepest flaw of Holmes' thought" was a tendency to prefer abstractions to "humane ends." Instead of giving attention to the pressing needs of interests at particular points in time, Faulkner argued, Holmes subscribed to a "fundamentally optimistic fatalism" which allowed history to usurp the role of the judge in doing justice. Holmes believed, according to Faulkner, that "man's interests are automatically ever better served ...." "[He] presupposed . . the justice of history."109

Critics of the 1960s expanded the concept of civil liberty in finding Holmes wanting as a civil libertarian. Writers of the 1920 s and 1930 s who had hailed Holmes as a champion of civil liberties had made assumptions about the nature of rights in civilized society different from those made by their counterparts in the 1960s. They had assumed that liberties-such as that of contract and that of speech-were not

108 Rogat, supra note 17, at 254-55, 24, 305, 308; Rogat, supra note 100, at 225.

100 R. FAULKNER, supra note 107, at 264-65, 263, 247-49. 
absolütes, but were subsumed in the consensual values of contemporary America. Their view was that expressed by Justice Brandeis in two decisions in 1921: "Rights . . must be remoulded, from time to time, to meet the changing needs of society."110 "All rights derive from the purposes of the society in which they exist; above all rights rises duty to the community." 111 They considered Holmes a libertarian because in certain decisions he had protected freedom of speech where it did not immediately threaten national interests. For Holmes, the liberty flowed not from any inherent right of the individual but from the interest of society in a free flow of ideas. By the 1960s, however, the standard of libertarianism had altered; a social definition of civil rights seemed inequitable. Racial equality seemed to demand a philosophical definition that provided for the inherent equality of individuals and the absolute nature of human rights. No longer could society have one standard of rights for one set of persons and a second for another-that constituted a deprivation of inalienable guaranties. In this context Holmes's easy approval of majoritarian discriminations against minorities appeared unconscionably nonlibertarian.

The 1960s marked the nadir of Holmes's image. Critics seemed unwilling to undertake charitable interpretations of any of his characteristics: his Brahminism was considered snobbishness, diffidence, and insensitivity; his ideological presuppositions were thought to exhibit both a shocking indifference to humanitarian values and a complacent insularity about the inevitability of progress. The great repute in which Holmes had been held in earlier years seemed to critics of the 1960s to be a glaring example of the distasteful set of values that had dominated American civilization in their immediate past. The ideal they held of a society whose guardians perceived the democratic and egalitarian principles at its core clashed with qualities and beliefs they found in Holmes.

\section{Holmes and the Critics: A Concluding Assessment}

Despite its diversity, the critical literature on Holmes almost uniformly fails to assess him on his own historical terms. Holmes was, first and foremost, a late nineteenth century intellectual radical. He was concerned with smashing existing fixed systems of the universe and substituting a fluid one. The Common Law was his most telling work-it was critical of the quasi-religious formalistic logic of his time and supportive of two fluid organizing concepts, history and community values. 
At the close of the nineteenth century, Holmes attempted through science to make the concept of community values a tangible, measureable one. In this task he foreshadowed the efforts of social planners in the early twentieth century. But as that century dawned, Holmes gave up his effort and came to rest on the belief that the universe was unknowable, that ultimate values were in the end merely personal prejudices, and that change come through the fluctuating superiority of such prejudices. Ultimately his ideology presumed an open and ever-changing system of intellectual intercourse-an unregulated market of ideas. This was his famous skepticism.

Because Holmes equated prevailing social values and ideals with prejudices, his ideology was profoundly apolitical. Late nineteenth century commentators made the mistake of identifying his intellectual radicalism with political radicalism. The progressives also erred in thinking that since Holmes believed in fluidity and change, he, like they, ascribed a positive value to change. But in giving up any belief in scientific measurement of social desires, Holmes had also given up a faith in the ability of social planners to achieve progress through an enlightened reordering of social priorities. If beliefs could not be measured, he felt, they could not be ranked. He thus rested on "what the crowd wants." The progressives, in contrast, wanted to educate the "crowd" to desire those things that the progressives believed rightthinking twentieth century Americans should desire.

The hero worshippers of the 1930s made a similar error in their evaluations of Holmes. They ascribed to him the positive as well as the negative components of attitudes, whereas Holmes held only the negative. Because Holmes believed that ideas should have free expressiona belief he often justified by saying that the process of airing those ideas would convince people of their absurdity-and because some of his free speech decisions had involved members of minority groups, Holmes became a protector of minorities and a transcendant Brahmin. His approach to free speech, in fact, assumed the ultimate impotence of all forms of unpopular expression. Because Holmes was critical of nineteenth century judicial formalism and had demonstrated a consciousness of the element of bias in judicial decision making, he was said to support the whole of realism. But Holmes did not believe that psychology was the major component of decision making, and he opposed the kind of empirical internal study of institutions that the realists advocated. Because Holmes had taken a passive stance toward state experimentive schemes in the 1910s and 1920s, critics of the 1930 s assumed that he would be not only equally passive toward the federal programs of the New Deal, but sympathetic to what the New 
Deal-represented. But Holmes had never been enthusiastic about paternalistic legislation. He took a fatalistic view of man's nature and muttered about who was going to "pay the bill."

The demythologizers of the 1940s, though more sensitive than their earlier predecessors to the complexities in Holmes, still regarded him as "dateless." His apolitical, laissez faire skepticism was read as the equivalent of those bogeys of the 1940s, pragmatism and totalitarianism. Only in the 1950s did intellectuals begin to see a gap between Holmes's universe and their own. This perception appeared largely in the form of strained efforts to make him "moral" in 1950s terms-to show that had he comprehended the horror of totalitarian regimes he would have demonstrated greater concern for political values.

The critics of the 1960s continued to view Holmes through the lens of contemporary events. Their annoyance at his apparent absence of concern for libertarian principles rested on an expanded definition of liberties. Like the progressives, writers of the 1960 s matched all previous eras against their own; Holmes, whose thought was shaped in a world that had far different notions of "liberty" and "equality," was destined to fall short of their standards.

But if Holmes asks, on one level, to be judged by the standards of his age, he invites, on another level, judgment by a more timeless standard: the capacity for being human. Here one finds a disturbing dissonance between Holmes's very conspicuous social and professional success-it is hard to imagine a life less marred by physical, social, or economic deprivations or one marked by a greater length and breadth of achievement-and his gloomy musings that "the crowd has substantially all there is," 112 that "we all are very near despair," 113 that men are like "flies,"114 and that man has no more cosmic significance than a baboon or a grain of sand. ${ }^{115}$ The specter of the eminent Holmes uttering such misanthropy smacks of the "old cardinal" prose of Henry Adams that Holmes himself decried. ${ }^{116}$

Holmes's skepticism appears to have been less a striving for a positive goal than a facile means of avoiding commitment, whether to beliefs, institutions, or mankind itself. One is struck by the comments of Holmes that he had remained childless because he could not bear bringing children into the world and because he preferred the less-involved

112 I HoLMES-LASKI LFTTERS 207 (M. Howe ed. 1953).

113 O.W. Holmes, Collected Legal Papers 248 (1920).

1142 Holmes-Laski LetTers 946 (M. Howe ed. 1953).

115 Cf. Howe, supra note 91.

110 Rogat, supra note 100 , at $230-31$. 
paternalism he felt for his law clerks. ${ }^{117}$ These statements suggest a desire to evade the responsibilities and emotional attachments of close involvement with other human beings, or perhaps the adoption of a misanthropic pose to prevent others from probing into areas of his life in which he felt vulnerable.

It is disappointing to find a man who was fortunate enough to be made aware in his lifetime of the full measure of his accomplishment (how many men are able to hear themselves called "the greatest of our age in the domain of jurisprudence, and one of the greatest of the ages"118?), yet who seemed to be so indifferent, at times savagely so, to the lives of his fellow mortals. To be sure, Holmes had his valuescivilization, the martial virtues, and, in his own sense, democracy and even liberty. He also had high standards of intellectual performance. But the richness of his mind, the power of his intellect, and even the depth of his feelings tended to degenerate into a cranky negativism that, given his stature, seems peculiarly distasteful. It is Holmes's articulated refusal to take pride in being human that marks him as one of the least "heroic" of America's heroes.

117 Letter and Memorandum from Learned Hand to Mark DeWolfe Howe, Apr. 29, 1959 , in M. HowE, supra note 102, at 8; Derby, supra note 64, at 352.

118 Cardozo, Mr. Justice Holmes, 44 Harv. L. Rev. 682, 684 (1981). 